\title{
Occurrence, Distribution, Biology and Management of Coffee Thread Blight (Corticium koleroga (Cke) Hoehnel): A Review
}

\author{
Nagassa Dechassa \\ Ethiopian Institute of Agricultural Research, Jimma Agricultural Research Centre, Jimma, Ethiopia
}

\begin{abstract}
Coffee is the key cash crop and top foundation in the world economy. Coffee thread blight caused by Corticium koleroga (Cke) Hoehnel is a devastating disease that causes severe damage to Coffee in major coffee producing countries. The disease is reported in India, Trindad, Tobego, Guatemala, Jamaica, Puerto Rico, Birazil, Ethiopia, Argentina, Brazil, Columbia, Venezuela, Mexico and United States. It infects areal parts of various crop species as Coffea spp., Camellia sinensis, Diospyros kaki, Pipper nigrum, Theobroma cacao, Citrus spp., Zingiber officinale, Mangifera indica and Hevea brasiliensis. The Corticium koleroga is characterized with colony colour ranging from white to floral white, with circular to irregular form and filiform to entire in margin on PDA plates. Growth rate of the pathogen is ranged between 6 and $9 \mathrm{~mm} /$ day in diameter. Basidiospore size ranged from 10 to $13.75 \times 3.75$ to $5 \mu$. Use of improved cultural practices (pruning out blighted twigs and shade tree management), use of resistant varieties, biological control by use of parasitic fungi (Gliocladium spp., Trichoderma spp., Verticillium spp.) play a role in controlling the disease. In addition Chemical control with cupric compounds, propiconazole, Agrozim, Bavistin, Bayleton, Foltaf, Plantvax, Tilt and Topsin-M are effective to control thread blight in coffee in extreme cases.
\end{abstract}

Keywords: Basidia, Basidiospore, Black rot, Hyphae, Koleroga, Mycilium

DOI: $10.7176 / \mathrm{JEES} / 9-2-01$

\section{Introduction}

Coffee is one of the highly preferred international beverages and the most important trade commodities in the world next to petroleum (ICO, 2012; FAO, 2015). It is the major sources of hard currency, source of revenue and contributes significant economic, social and spiritual impact for millions of communities in Africa, Asia and Latin America with diverse cultural and/or psychological backgrounds (Chauhan et al., 2015).

Even though coffee is the key cash crop and top foundation of the world economy; numerous production constraints have been affecting the production and productivity of the crop. Abiotic and biotic factors are the major constraints of coffee production in the world among which are fungal diseases attacking fruits, leaves, stems and roots, and reduce the yield and marketability. A number of coffee diseases along with their causal pathogens have been identified and documented on C. arabica. Coffee berry disease (Colletotrichum kahawae), Coffee wilt disease (Gibberella xylarioides) and Coffee leaf rust (Hemileia vastatrix) have been grouped as major coffee diseases (Adugna et al., 1997; Derso et al., 2000). Whereas Coffee thread blight (Corticium koleroga), Coffee bacterial blight (Pseudomonas syringae), Root rot (Armillaria mellea), Bean discoloration/rot (Pseudomonas syringae), Brown blight (Colletotrichum gloeosporioides), Ascochyta leaf blight and Shoot die-back (Ascochyta tarda), Seedling damping-off (Rhizoctonia spp., Phytium spp., Fusarium spp. and Mucor spp.) are considered as minor and locally important diseases of coffee (Teferi et al., 2008).

Coffee is under the threat of both the co-evolved diseases (which have evolved with the host in its centre of origin) and the new encounter diseases (which have resulted from the adaptation of a native pathogen to an introduced crop mainly) due to increasing South-South trade. This situation could lead to the introduction to new territories of co-evolved diseases like Coffee wilt disease caused by Fusarium xylarioides confined so far to Africa, or of encounter diseases like Coffee berry disease caused by Colletotrichum kahawae only present in Africa and the American leaf spot disease caused by Mycena citricolor located in America only (Bieysse et al., 2008).

According to Cavalcante and Sales (2001) thread blight caused by the phytopathogenic fungi (Corticium koleroga) is an important disease of Coffee in India, Trindad and Tobego. In Ethiopia the disease had first been recorded in 1978 at Gera and Mettu Agricultural Research Sub-centres (Derso et al., 2000). Thread blight diseases on Ethiopian coffee was known for more than 40 years and considered as minor coffee disease. But it is increasingly becoming an important disease and has been observed in wide coffee growing regions of Ethiopia as an epidemic disease in 2014 (Belachew et al., 2015). Therefore, the objective of this paper is to review the occurrence, distribution, biology and management options of Coffee thread blight disease caused by Corticium koleroga.

\section{Occurrence and Distribution of Coffee Thread Blight Disease}

Thread blights attack the aerial parts of a number of plants, particularly coffee, citrus, pomes, tea, cacao and fig trees (Gasparotto and Silva 1999; Pereira et al., 2000; Benchimol et al., 2001). The three major thread blights are koleroga or black rot, Marasmoid thread blights and Horse hair blight. All three are caused by basidiomycycetes 
(Muller et al., 2009). Marasmoid thread blights caused by Marasmius scandens Mas are similar in appearance to koleroga. A fine film of greyish mycelium envelops the leaves and the twigs causing the leave to wither and die. Again they remain hanging within the enveloping mycelium. Horse hair blight caused by Marasmius equicrinis, long thin black threads develops on the leaves and twigs. These threads are capped by tiny fungal carpophores (Muller et al., 2009).

The concern of this review is directed towards Coffee Thread Blight (CTB) or koleroga or black rot which is caused by Corticium koleroga which is a devastating disease that causes severe damage to coffee in many coffee growing areas. It attacks all coffee plant parts except the root (Ceresini et al., 2012). Koleroga means rot disease in the Kannada language of Karnataka, in India (Roberts, 1999). CTB has first been reported on coffee by Cooke in 1876 in India (Tims et al., 1954). Since then the disease prevails on every continent and on many varieties of woody plants like citrus, ficus and cocoa (Muller et al., 2009). According to Cavalcante and Sales (2001) CTB caused by the phytopathogenic fungi (Corticium koleroga) is an important disease of Coffee in India, Trindad and Tobego. It is detected in both shaded and non-shaded coffee plantations, although at low and high altitudes in various Central American countries (Muller et al., 2009). In America, CTB has been reported in Argentina, Brazil, Columbia, Venezuela and the Guianas, in several Central American countries, Mexico and the United States (Tims et al., 1954; Ceresini et al., 2012). Thread blights have become a serious problem in western Guatemala and are also a serious concern in the Chiapas state of Mexico and in the lake Yojoa region (Muller et al., 2009). Burt (1926) identified C. koleroga on coffee in Mysore, Porto Rico, Colombia and Venezuela. It has been reported from Asia (India and Vietnam) and from the Americas (Colombia, Guatemala, Jamaica, Puerto Rico, Trinidad, United States and Venezuela) (Roberts, 1999).

The first report of thread blight disease in Brazil dates back to 1978, on Pomelo (Citrus maxima) orchard in the Amazon region (Rosseti et al., 1982). It is considered as an emerging plant disease for Brazilian crop species especially coffee (C. arabica, C. canephora), persimmon (Diospyros kaki L.) and tea (Camellia sinensis L.) (Cavalcante and Sales, 2001).

In Ethiopia the disease had first been recorded in 1978 at Gera and Mettu (Derso et al., 2000; Teferi et al., 2008 ) and it is increasingly becoming an important disease and has been observed in wide coffee growing regions of Ethiopia as an epidemic disease since 2014 (Belachew et al., 2015; Dechassa, 2018).

\section{Host Range of Thread Blight}

The thread light disease caused by Corticium koleroga is considered as an emerging and has a very wide hosts ranging from annual herbaceous monocots to perennial woody fruit trees, which is extremely difficult to control and result in significant economic losses (Gasparotto and Silva, 1999; Ceresini et al., 2012). It is reported by several workers occurring in mild to severe form on a variety of hosts belonging to the most diverse families of tree crops. It infects areal parts of various crop species as Coffee (C. arabica and C. canephora), Black pepper, Capsicum, Citrus, Ginger (Zingiber officinale), Mahogany, Tea and Persimmon (Burt, 1926; Ceresini et al., 2012). According to the report by Lourd and Alves (1987), 27 plant species were hosts for this pathogen in the Amazon. Another 18 species of native fruit trees from the Amazon were subsequently described as hosts for C. koleroga (Gasparotto and Silva, 1999). It has been reported to affect Soursop (Annona muricata L.), Black pepper (Pipper nigrum L.), Cacao (Theobroma cacao L.), Citrus spp., Coffee (Coffea arabica L), Mango (Mangifera indica L.), Rubber trees (Hevea brasiliensis) and several other tree species (Rosseti et al., 1982; Pereira et al., 2000; Benchimol et al., 2001).

\section{Growth Factor Requirements of Corticium koleroga}

The fungus Corticium koleroga grew well on a number of agar media containing fresh extracts of potato, onion, carrot, oat, bean and malt, while it is poorly grown on a dextrose nitrate medium. However, when small quantities of malt, yeast, coffee leaf or malt extracts are added to the dextrose nitrate medium, it grows better (Mathew, 1953; Ceresini et al., 2012).

\section{Factors Favouring Coffee Thread Blight}

The result of the current study by Dechassa (2018) indicated that, increased level of rainfall and relative humidity were associated with an increased risk of CTB disease development on C. arabica. Besides, disease intensity was the highest at midland and highland altitudes, plantation coffee production systems, open shade level and local coffee varieties. According to Belachew et al. (2015) heavy, long and continuous rainfalls as well as higher relative humidity from the month of June to September has triggered thread blight disease outbreak in 2014 at most coffee growing areas of Ethiopia. Susceptible coffee genotypes, heavy shade and build up of diseases causing pathogens are also factors contributing to the occurrence and outbreaks of coffee thread blight. Similar report by Mathew (1953); Adugna et al. (2009) also indicate that the development of thread blight was favoured by continuous and heavy rainfall, high atmospheric humidity and overhanging branches. 


\section{Mechanisms of Disease Transmission}

Disease dispersal has occurred through human activities and by the introduction of infected plants in disease free areas. C. koleroga is an aerial pathogen transmitted by free water and splashing over short distances. Lines of expansion over longer distances follow roads or are due to accidental transportation of infected planting material over long distances. The spread of the disease is assisted by wind, water, insects as well as mechanical means (Mathew, 1953; Adugna et. al., 2009; Muller et al., 2009). The disease spreads mainly by the fungus threads (hyphae) growing from leaf to leaf or along branches within a tree and from tree to tree through infected fallen branches from tall shade trees. It also spreads through airborne basidiospores released from basidia formed during wet weather. The disease might also be spread by Antestia bug (Antetsopsis antiricata), Usingeria mirabilis (Muller et al., 2009).

\section{Mode of Penetration}

The thread blight pathogen of coffee overwinters as mycelium and fruiting structures in coffee stalks and spreads by means of imperfect stage and disease progresses through the rainy season (Burt, 1918). Burt (1926) emphasized that Corticium koleroga could penetrate the outer layers (bark) of coffee tree. Narasimhan (1933) stated that under favourable conditions for infection, the fungus could enter the healthy branches through lenticels as well as through wounds. Narasimhan (1933) observed that hyphae emerging from the compact masses of pseudoparenchymatous cells of $C$. koleroga, the cause of black rot of coffee leaves entered the leaf tissues through the stomata and penetrated the spongy parenchyma often reaching the palisade cells.

\section{Biology of Coffee Thread Blight Causing Pathogen Symptoms of Coffee Thread Blight in the Field}

In the field, thread blight disease on $C$. arabica appear as thread-like white to ashen strand on the middle stem of the coffee tree at first then the black plus whitish strands of nodes, internodes of the twigs. The blackening of leaf petiole later spread to leaf blade predominantly on the lower surfaces of leaves. The strands always branch off from the leaf petioles to leaves and then spread out into numerous fine ones. The fine strands initiated dark-ashen necrosis and as the whole leaf became involved, the leaf separated at the petiole but usually remained hanging from mycelial strand that grew over the petiole from the branch. On berry the sunken black with ashen mycilial strands was seen as necrotic symptom of the disease (Dechassa, 2018).

The parasitic vegetative mycelium forms long, slender, mycelial strands of rather uniform diameter, whitish or pallid at first. Then fuscous, running along the branches and midrib and veins of the leaves, infecting the leaves and ramifying between the cells of the leaf parenchyma. Finally emerging at many points on the underside of the leaf to form minute fructifications which give a mottled appearance to the leaf; fructifications soon laterally confluent into a thin, arachnoids, perforate membrane covering the under surface of the leaf between midrib and principal veins, drying pale smoke-gray, separable in small pieces, composed of loosely interwoven, hyaline or slightly coloured, thin-walled, even and rigid hyphae (Burt, 1918).

The colony colour of $C$. koleroga is from white to floral white, with circular to irregular form and filiform to entire in margin on PDA plates. Its growth rate ranges between 6 and $9 \mathrm{~mm} /$ day in diameter on PDA plates. Its growth rate increases from two to eight days but decreases 9 days after incubation at $25^{\circ} \mathrm{C}$ (Dechassa, 2018).

The hypha is 4.5 to $6 \mu$ in diameter, not nodose-septate, branched at right angles and running parallel with the substratum (Burt, 1918). According to Roberts (1999) Microscopically C. koleroga has colour less hyphae, 3 to $5 \mu$ wide, without clamp connections. Currently the study by Dechassa (2018) authenticated that pure culture of $C$. koleroga showing long, hyaline, wide angled branching mycilia and more or less uniform hyphal width measuring 3.75 to $5.00 \mu$ were observed under microscope.

The basidia are ellipsoid to broadly club-shaped (Roberts, 1999). According to Rogers (1947), C. koleroga is characterized by basidia which are not septate, do not possess stout, swollen sterigmata and which produce basidiospores which germinate directly to form a mycelium. The same author had given a clear account for basidia of $C$. koleroga, terming them apobasidia with the definition of an apobasidium as a basidium whose basidiospores are not apiculate. He grouped C. koleroga under a group of Homobasidiomycetes (group possessing basidia which are not septate) other than a Heterobasidiomycete (group possessing basidia which are septated). According to Dechassa (2018) Corticium koleroga is characterized by basidia, which are ellipsoid to oblong in shape, hyaline in color, not septate, thicker than width of supporting hyphae on which 4-6 basidiospores are directly fixed. It produces the primary bacidial cell (probasidium) which is preceded by the final stage of the basidium (metabasidium) which is collapsed after spore formation.

According to Burt (1918), C. koleroga produces basidiospores hyaline, even, flattened or slightly concave on one side, measuring 10-13 x 3.5-5 $\mu$ size. Basidiospores of $C$. koleroga appeared as smooth, hyaline, narrow and fusiform in shape measuring 10 to $13.75 \mu \times 3.75$ to $5 \mu$ in size (Dechassa, 2018). The basidiospores are narrow and fusiform, 9 to $13 \times 3$ to $5 \mu$ (Roberts, 1999). 


\section{Management of Coffee Thread Blight}

Thread blight disease has been known on many crops including coffee in many countries for many years (Gasparotto and Silva, 1999; Cavalcante and Sales, 2001; Ceresini et al., 2012) but few studies have been conducted on its management since the potential threat of the disease to production. The disease is widespread on coffee with high rates of incidence and severity in the coffee growing areas of Southwest Ethiopia since most farmers have limited knowledge about the disease and were therefore indifferent towards its control resulting in increasing disease incidence and severity (Teferi et al., 2008; Belachew et al., 2015).

\section{Cultural Practices}

Use of improved cultural practices can play a role in controlling the disease. Optimizing shade and avoiding poorly ventilated areas when selecting an orchard site should help prevent the disease. Under light disease pressure, pruning out blighted twigs and branches and shade tree management may provide adequate disease control. Pruning compacted coffee varieties to promote better penetration of sunlight and air may also help suppressing the disease (Teferi et al., 2008) and ddiseased branches should be cut off and burnt (Muller et al., 2009).

\section{Host Resistance}

Disease control by use of resistance variety is one of the disease management components in integrated disease management. Diseases resistant varieties not only have the potential to reduce the cost of production but also offer an environmentally safe disease management approach. In resistant genotypes cork formation effectively seals off the invading tissue and serves as main resistant mechanisms (Adugna and Jafuka, 2008). The diseases development and severity varies among different coffee varieties and plant parts. The use of resistant variety plays in combating coffee thread blight disease (Teferi et al., 2008; Belachew et al., 2015; Dechassa, 2018).

\section{Chemical Control Method}

Muller et al. (2009) recommended that chemical control with cupric compounds can be used in extreme cases of thread blight disease on coffee. The efficiency of triazoles fungicides (propiconazole) was confirmed by Sudhakar and Shankara (1995) in the control of Corticium koleroga in coffee. The fungicides Agrozim 50 WP, Bavistin 50 WP, Bayleton 25 EC, Foltaf 80 WP, Plantvax 20 EC, Tilt 25 EC and Topsin-M 70 WP were effective to control thread blight disease in coffee (Sudhakar and Shankara, 1992). Spraying of carbendazim (Bavistin 50 WP) $0.03 \%$ active ingredient and Bordeaux mixture 1\% active ingredient were effective in controlling thread blight disease in coffee (Sudhakar and Shankara, 1995).

\section{Biological Control Method}

Biological control of plant diseases is increasingly receiving attention, not only to reduce the dependence on chemicals having hazardous effect in ecosystem (Upadhyay and Rai, 1983) but to adapt it to the conceptual scheme of integrated pest management as an acceptable ecosystem approach (Papavizas and Lumsden, 1985). Biocontrol has been most successful against diseases of woody plants (Campbell, 1989) because traditionally little breeding work has been done for resistance in trees and that very few pesticides have developed specifically for tree diseases. It appeared to be a promising strategy for managing foliar and fruit diseases in number of crops (Sutton and Peng, 1993).

Jansen (2005) noticed parasitic fungi (Gliocladium spp., Trichoderma spp., Verticillium spp.) showed antagonistic properties against Corticium spp. (C. salmonicolor and C. koleroga) affecting coffee production. Of the various fungal microorganisms used as antagonists, Trichoderma species were extensively exploited by pathologists due to wide distribution (Campbell, 1989) and their higher efficacy, broad spectrum activity and ease in isolation and cultivation (Mukhopadhyay and Mukherjee, 1996). Besides, Trichoderma species, Streptoverticillium sp., Laetisaria arvalis, Coniothyrium minitans. Aspergillus spp., Penicillium spp., and non pathogenic species of Fusarium could be successfully exploited for biocontrol of plant disease (Muthusamy, 1999). Amongst the bacterial antagonists, Bacillus subtilis, Pseudomonas fluorescens and Agrobacterium radiobacter were widely and commonly practiced.

In conclusion Coffee thread blight caused by Corticium koleroga (Cke) Hoehnel is a devastating disease that causes severe damage to Coffee in major coffee producing countries in the word. The occurrence and distribution of the disease is reported in India, Trindad, Tobego, Guatemala, Jamaica, Puerto Rico, Birazil, Ethiopia, Argentina, Brazil, Columbia, Venezuela, Mexico and United States. In addition to Coffea spp., it infects areal parts of various crop species as Camellia sinensis, Diospyros kaki, Pipper nigrum, Theobroma cacao, Citrus spp., Zingiber officinale, Mangifera indica and Hevea brasiliensis. In the field, thread blight disease on C. arabica appear as thread-like white to ashen strand on coffee tree parts. Corticium koleroga is characterized with colony colour ranging from white to floral white, with circular to irregular form and filiform to entire in margin on PDA plates. Growth rate of the pathogen is ranged between 6 to $9 \mathrm{~mm}$ /day in diameter. It possesses basidia having two stages probasidia and metabasidia. Basidiospores of C. koleroga appeared as smooth, hyaline, narrow and fusiform in 
shape measuring 10 to $13.75 \mu \times 3.75$ to $5 \mu$ in size. The disease can be controlled by use of improved cultural practices (pruning out blighted twigs and shade tree management); use of resistant varieties and biological control by use of parasitic fungi (Gliocladium spp., Trichoderma spp., Verticillium spp.). Chemical control with cupric compounds, propiconazole, Agrozim, Bavistin, Bayleton, Foltaf, Plantvax, Tilt and Topsin-M are effective to control thread blight disease in coffee in extreme cases.

\section{REFERANCES}

Adugna G 1997. Status and economic importance of Fusarium wilt disease of Arabica coffee in Ethiopia. In: Hakiza G, Birkunzira B, Musoli P (eds.) Proceedings of the first Regional Workshop on Coffee Wilt Disease. International Conference Centre, Kampala, Uganda. pp.53-61.

Adugna G, Jafuka C (2008). Resistance levels of arabica coffee cultivars to coffee berry disease, coffee wilt disease and coffee leaf rust in Ethiopia. In: Proceedings of the $12^{\text {th }}$ Crop Science Society of Ethiopia, Addis Ababa, Ethiopia. 12: pp. 92-103.

Adugna G, Jafuka C, Zeru A, Tessfaye A (2009). Advances in Coffee Diseases Research in Ethiopia. Increasing Crop Production through Improved Plant Protection. Plant Protection Society of Ethiopia (PPSE), Addis Ababa, Ethiopia, pp.19-22.

Belachew K, Teferi D, Hagos L (2015). Coffee Thread Blight (Corticium koleroga): a Coming Threat for Ethiopian Coffee Production. J. Plant Pathol. Microb. 6:303-308.

Benchimol L, Poltronieri S, Trindade R, Albuquerque C (2001). White thread blight: Five new hosts in the State of Pará, Brazil. Fitopatol. Bras. 26: 778-778.

Bieysse D, Cilas C, Mouen J, Musoli P, Avelino J (2008). Coffee Disease Risk Analysis: How Epidemiology Knowledge Could Help In Assessing and Preventing Disease Invasion. Proceedings of $22^{\text {nd }}$ International Conference on Coffee Science, pp. 1422-1423.

Burt A (1918). Corticium Causing Pellicularia disease of the coffee, Hypochnose of Pomaceous fruits and Rhizoctonia disease. Ann. Mol. Bot. Gard. 5: 119-132.

Burt A (1926). Thelephoraceae of North American Corticium. Ann. Mo. Bot. Gard. 13:173-354.

Cavalcante M, Sales F (2001). Ocorrência da queima-do-fio (Pellicularia koleroga) Emcafezaisem Rio Branco. Empresa Brasileira de Pesquisa Agropecuaria-Embrapa Acre, Rio Branco.

Cavalcante M, Sales F (2001). Ocorrência da queima-do-fio (Pellicularia koleroga) Emcafezaisem Rio Branco. Empresa Brasileira de Pesquisa Agropecuaria-Embrapa Acre, Rio Branco.

Ceresini C, Costa-Souza E, Zala M, Furtado L, Souza L (2012). evidence that the Ceratobasidium like white thread blight and black rot fungal pathogens from persimmon and tea crops in the Brazilian Atlantic Forest agro-ecosystem are two distinct Phylo Species. Genetic and Molecular Biology 35: 480-497.

Dechassa N (2018). Survey of Coffee Thread Blight (Corticium Koleroga (Cke) Hoehnel) In Southwest Ethiopia and Evaluation of Some Coffea Arabica L. Genotypes for Resistance against the Disease. MSc Theses, Hawassa University, Ethiopia. 100p.

Derso E, Gebrezigi T, Adugna G (2000). Significance of Minor Diseases of Coffea arabica L. in Ethiopia. A Review In: Proceedings of the Workshop on Control of Coffee Berry Disease in Ethiopia, August 1999, Addis Ababa, Ethiopia. pp. 58-65.

Gasparotto L, Silva L (1999). New hosts of Pellicularia koleroga in the State of Amazonas, Brazil. Fitopatol. Bras. 24: 460-469.

Mathew T. 1953. Studies on Black Rot of Coffee. Doctoral Dissertation. University of Madras Botany laboratory.

Muller A, Berry D, Avelino J, Biesse D (2009). Coffee Diseases. Jean Nicolas (ed.). Coffee: Growing, Processing, Sustensble Production: A Guide book for Growers, Processers, Traders and Researchers, pp.495-549.

Narasimhan J (1933). Black rot of coffee in Mysore. Phytopathology 23: 875-886.

Pereira C, Ledo J, Bergo L, Siviero A (2000). Evaluation of Arabica and Robusta Coffee Genotypes in Western Amazonia. Acta Amazonica 30: 535-541.

Roberts P (1999). Rhizoctonia Forming Fungi. Royal Botanic Gardens, 239p.

Rosseti V, Alves M, Clement C (1982). Ocorrência de Pellicularia koleroga Empomare Scítricosna Amazonia. Fitopatol. Bras. 7: 518-526.

Sudhakar B, Shankara B (1992). In Vitro Studies on the Efficacy of Fungicides against Koleroga noxia on Coffee. Coffee Research 22: 57-64.

Sudhakar B, Shankara B (1995). Effect of bavistin 50 WP and Bordeaux Mixture for the Control of Black Rot and Their Impact on Coffee Yield. Coffee Research 25: 35-41.

Teferi D, Adugna G, Jafuka C, Tesfaye S, Zeru A, Mesfin S (2008). Dynamics of Sporadic Diseases of Coffee in Ethiopia: A Review. In: Diversity and Knowledge; Proceeding of National Work shop Four Decades of Coffee Research and Development in Ethiopia. pp. 267-270.

Tims C, Mills J, Exner B (1954). Thread Blight (Pellicularia koleroga) in Louisiana. Plant Disease 38: 634-637. Upadhyay S, Rai B (1983). Mycoparasitism with reference to biological control of plant diseases. Recent Advances 
in Plant Pathology 1: 48-72.

Sutton C, Peng G (1993). Manipulation and Vectoring of Biocontrol Organisms to Manage Foliage and Fruit Diseases. Annu. Rev. Phyto. 1: 473-493.

Papavizas C (1985). Trichoderma and Gliocladium Biology, Ecology and Potential for Biocontrol. Annu. Rev. Phyto. 1: 23-24.

Campbell R (1989). Biological Control of Microbial Plant Pathogens. Cambridge University Press, Cambridge. $218 \mathrm{p}$

Jansen E (2005). Plant Protection in Coffee Recommendations for the Common Code for the Coffee CommunityInitiative.

Mukhopadhyay N, Mukherjee K (1966). Fungi as Fungicides. International Journal of Tropical Plant Diseases 14 : $1-7$.

Muthusamy M (1999). Biofungicides Effective Tools for the Management of Plant Diseases. Pestologyli, 1: 185187. 